\title{
Response of Litchi cultivars to rooting through air layering in different growth media
}

\author{
Nadeem Khan ${ }^{1 *}$, Haji Muhammad ${ }^{2}$, Shahid Rahman ${ }^{1}$, Fazal Ghafoor ${ }^{1}$, \\ Said Rawan ${ }^{1}$, Abid Kamal ${ }^{3}$, Taufiq Ahmad ${ }^{1}$, Farid Ullah ${ }^{1}$, Ghani Gul ${ }^{1}$, \\ Shah Faisal ${ }^{1}$, Umair Anwar ${ }^{1}$ and Aliman Shah ${ }^{1}$ \\ 1. Department of Horticulture, The University of Agriculture, Peshawar-25130-Pakistan \\ 2. Director of AED Batkhela at Malakand-Pakistan \\ 3. Department of SES, The University of Agriculture, Peshawar-25130-Pakistan \\ *Corresponding author's email: nadeemaup25@gmail.com \\ Citation \\ Nadeem Khan, Haji Muhammad, Shahid Rahman, Fazal Ghafoor, Said Rawan, Abid Kamal, Taufiq Ahmad, Farid \\ Ullah, Ghani Gul, Shah Faisal, Umair Anwar and Aliman Shah. Response of Litchi cultivars to rooting through air \\ layering in different growth media. Pure and Applied Biology. Vol. 5, Issue 4, pp862-867. \\ http://dx.doi.org/10.19045/bspab.2016.50108
}

Received: 01/04/2016

Revised: 29/07/2016

Accepted: 10/08/2016

Online First: 17/08/2016

\section{Abstract}

An experiment on 'Response of Litchi cultivars to rooting through air layering in different growth media" was conducted at Fruit Nursery farm Jabban Dargai, Malakand during 2014. Air layering was done in June on different varieties (Surriya and Golla) in different media (sawdust, silt, garden soil and sawdust +silt +garden soil). The experiment was laid out on a randomized complete block design having three replications. The research revealed significantly different results for days to rooting, number of roots per plant, root length, root diameter and percent survival among the varieties. Similarly different growth media also significantly affected most of the parameters studied. Maximum number of roots $(9.5)$, root length $(3.35 \mathrm{~cm})$, root diameter $(0.15 \mathrm{~cm})$, percent survival $(79.17 \%)$ and minimum days to appearance $(25)$ were recorded for cultivar Surriya (28), while the maximum number of roots $(11.17)$, root length $(3.61 \mathrm{~cm})$, root diameter $(0.17 \mathrm{~cm})$ and percent survival $(83.33 \%)$, and minimum days to appearance (23) were recorded in silt. On the basis of these results variety Surriya and Silt as a rooting medium were found the best and hence recommended for rooting of Litchi varieties through air layering.

Key words: Litchi; Varieties; Rooting; Air layering; Growth media

\section{Introduction}

Litchi is botanically designated as Litchi chinensis, belonging to family Sapindaceae, widely grown in the subtropical as well as tropical area of the world [1]. In the subtropical area it is growing for better yield and quality producing fruits. It's medicinal and health value, high prices and demand in the market has created new opportunity for propagating through new materials.

Normally Litchi has been propagated vegetatively by different methods. Airlayering improve the younger branches, tree structure, quality fruits, healthy branches by proper method of propagation and time [2], since these fruits have a high flesh to seed ratio. Propagation by seeds produce plants but not healthy to vegetatively. From seeds 
the new plants produce female in number but by air-layering the progeny true to type to parents. The growth is faster than seeds [3]. Litchi is propagated invitro but as compare to vegetatively less survive [4]. By the secretion of polyphenols in the media, these polyphenols cause oxidation to produce substances that kill the tissues [5]. One of the major problems is that Litchi material grown used as a source of known genetic material, are highly contaminated with different organisms, which are difficult to remove prior to culture. To overcome these problem selection of younger branches for layering to increase the life of the trees [6]. [7] studied that media for propagation selection is important to provide crucial environment for root growth. FYM provide complete growing area for propagated materials. Selection of the best cultivar for propagation requires well organic media [5]. From this experiment to find out the best media for best cultivar of Litchi under vegetatively propagation by air-layering.

\section{Materials and methods}

An experiment on 'Response of Litchi cultivars to rooting through air layering in different growth media" was conducted at Government Fruit Nursery Farm, Jabban Dargai Malakand, during June 2014. Air layering was done in June on different cultivars (Surriya and Golla) in different media (Saw dust, silt, garden soil and Sawdust + Silt + Garden soil). The experiment was laid out in Randomized Complete Block Design (RCBD), having three replications. In order to initiate rooting in Litchi branches, seven year old tree, 24 trees was selected for layering, $1.5 \mathrm{~m}$ branch height and pencil size of each branch for layering, three layering was done in each tree, stem was wounded by complete removal of ring bark just below the buds in the month of June. Data were collected after 20 days. Different media were surrounded around the injured portion of the branch of
Litchi plant by heavy wrapping of burlap with plastic sheet. When a good ball of roots had formed, the branches were cut off below the media and data were recorded for different parameter.

\section{Selection of the media}

Saw dust, silt, garden soil and their mixture was used because of before using media it was confirmed that media were free of pathogens, weeds, pests, nematodes, having good water holding capacity and drainage. Different varieties and media were allotted to the plots shown as follow. Air layering was done in June on different cultivars (Surriya and Golla) in different media (Saw dust, silt, garden soil and Sawdust + Silt + Garden soil). The following parameters were measure during the experiment. Total number of days to root appearance and their averages was calculated after the date of airlayering and media treatments were recorded in each treatment. Number of roots plant-1 was counted and length of roots was measured with the help of measuring tape. The root thickness of primary root part was measured with the help of vernier caliper in centimeter and the averages were calculated for statistical analysis. At the end of experiment, the plants were counted; survival plant $\%$ ages were recorded by the following formula:

Survival percentage $=$ Number of plants survived $x 100$

Statistical analysis Total number of plants

The data recorded on different attributes were analyzed by using the statistical software. Analysis of variance (ANOVA), LSD test and comparison of the mean significant value to find out the differences among treatments and interaction [8].

\section{Result and discussion}

\section{Number of roots plant ${ }^{-1}$}

Data regarding number of root plant $^{-1}$ of Litchi cultivars were significantly affected by different growing media, interaction of cultivars and media were also found significant (Table 1). Maximum number of 
roots (9.50) plant $^{-1}$ was obtained at Surriya cultivar while Golla cultivar resulting minimum roots (7.92) plant $^{-1}$ of Litchi cultivar. Higher number of roots (11.17) plant $^{-1}$ was found in media silt, least number of roots (6.67) plant $^{-1}$ was noted in Sawdust media. Interactive effect of Litchi cultivar Surriya and silt media performed better on the number of roots plant ${ }^{-1}$ as compared to cultivar Golla and other media (Sawdust, Ground soil and SD+GS+S) (Figure. 1).

The silt had more nutrients as compared to the other media, and the saw dust had less nutrients. The findings of [9] to some extent support our results. The combination of the media enriched with nutrients from silt and garden soil, increased water holding capacity and proper aeration probably provided an ideal environment to Cv.Surriya to have more roots plant $^{-1}$. Silt retain more water than garden soil, saw dust media [10], and therefore plants grown in silt in our study required longer intervals between watering events. These results are in accordance to those of [11], who observed that growing large size roots in media silt with more organic matter content produced maximum roots number.

Table 1. Number of root plant ${ }^{-1}$, root diameter $(\mathrm{cm})$, root length $(\mathrm{cm})$, NDA and survival \% as affected by different media and Litchi cultivars

\begin{tabular}{|c|c|c|c|c|c|}
\hline & & Parameter & & & \\
\hline Cultivar & Number of root plant ${ }^{-1}$ & Root diameter & Root length (cm) & NDA & Survival \% \\
\hline Surriya & $9.5 \mathrm{a}$ & $0.15 \mathrm{a}$ & $3.35 \mathrm{a}$ & $25 \mathrm{~b}$ & $79.17 \mathrm{a}$ \\
\hline Golla & $7.92 \mathrm{~b}$ & $0.13 \mathrm{~b}$ & $2.91 \mathrm{~b}$ & $26.5 \mathrm{a}$ & $66.67 \mathrm{~b}$ \\
\hline $\mathrm{LSD}_{0.05}$ & 0.36 & 0.01 & 0.13 & 0.74 & 11.7 \\
\hline \multicolumn{6}{|l|}{ Media } \\
\hline Saw Dust & $6.67 \mathrm{c}$ & $0.12 \mathrm{~d}$ & $2.45 \mathrm{~d}$ & 29 & $50 \mathrm{c}$ \\
\hline Silt & $11.17 \mathrm{a}$ & $0.17 \mathrm{a}$ & $3.61 \mathrm{a}$ & 23 & $83.33 \mathrm{a}$ \\
\hline Garden soil & $8 \mathrm{~b}$ & $0.14 \mathrm{c}$ & $3.17 \mathrm{c}$ & 26.17 & $79.17 \mathrm{~b}$ \\
\hline $\mathrm{SD}+\mathrm{S}+\mathrm{GS}$ & $9 \mathrm{~b}$ & $0.15 \mathrm{~b}$ & $3.3 \mathrm{~b}$ & 25 & $79.17 \mathrm{~b}$ \\
\hline $\mathrm{LSD}_{0.05}$ & 0.51 & 0.01 & 0.18 & 1.05 & 16.55 \\
\hline \multicolumn{6}{|c|}{ Interaction (CV x Media } \\
\hline $\mathrm{LSD}_{0.05}$ & 0.71 & 0.01 & 0.25 & ns & ns \\
\hline
\end{tabular}

NDA: Number of days to appearance

Means followed by similar letters are statistically non-significant / similar at $5 \%$ level of significance

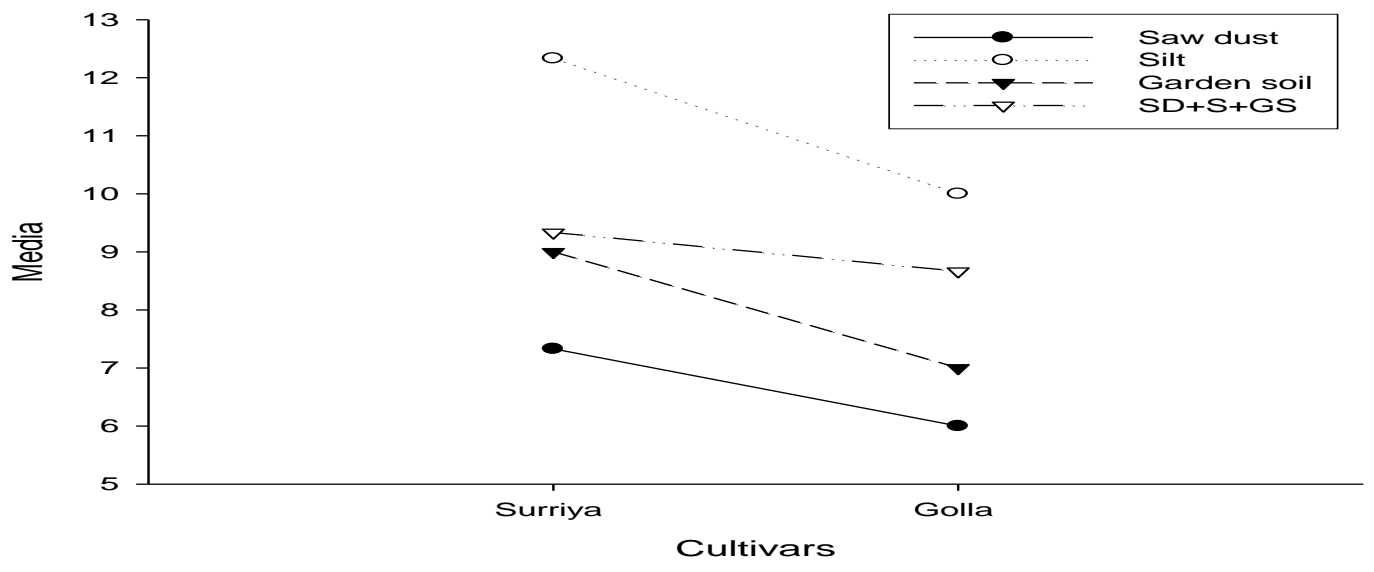

Figure 1. Interactive effect of cultivars and growing media on number of roots plant ${ }^{-1}$ 


\section{Root diameter (cm)}

Root diameters (cm) plant $^{-1}$ of Litchi cultivars were significantly affected by different growing media, interaction of cultivars and media were also found significant (Table-1). Maximum of root diameter $(0.15 \mathrm{~cm})$ plant $^{-1}$ was obtained at Surriya cultivar, while Golla cultivar resulting minimum root diameter $(0.13 \mathrm{~cm})$ plant $^{-1}$ of Litchi cultivar. Maximum root diameter $(0.17 \mathrm{~cm})$ plant $^{-1}$ was found in media silt, least root diameter $(0.12 \mathrm{~cm})$ plant $^{-1}$ was noted in Sawdust media. Interactive effect of Litchi cultivar Surriya and silt media performed better on the number of roots plant ${ }^{-1}$ as compared to cultivar Golla and other media (Sawdust, Ground soil and SD+GS+S) (Figure. 2).The media have been good drainage and high porosity that helped in the development of excellent root system. Such media enhances roots activities and cambial cell division. These combinations of the media provided favorable physical conditions for sufficient nutrients access to the cuttings which are needed for activating enzymatic and biochemical processes. The results of [12] are also in agreement with our findings who reported that soil media of silt + saw dust gave maximum number of root diameter in fruit trees propagation through air layering.

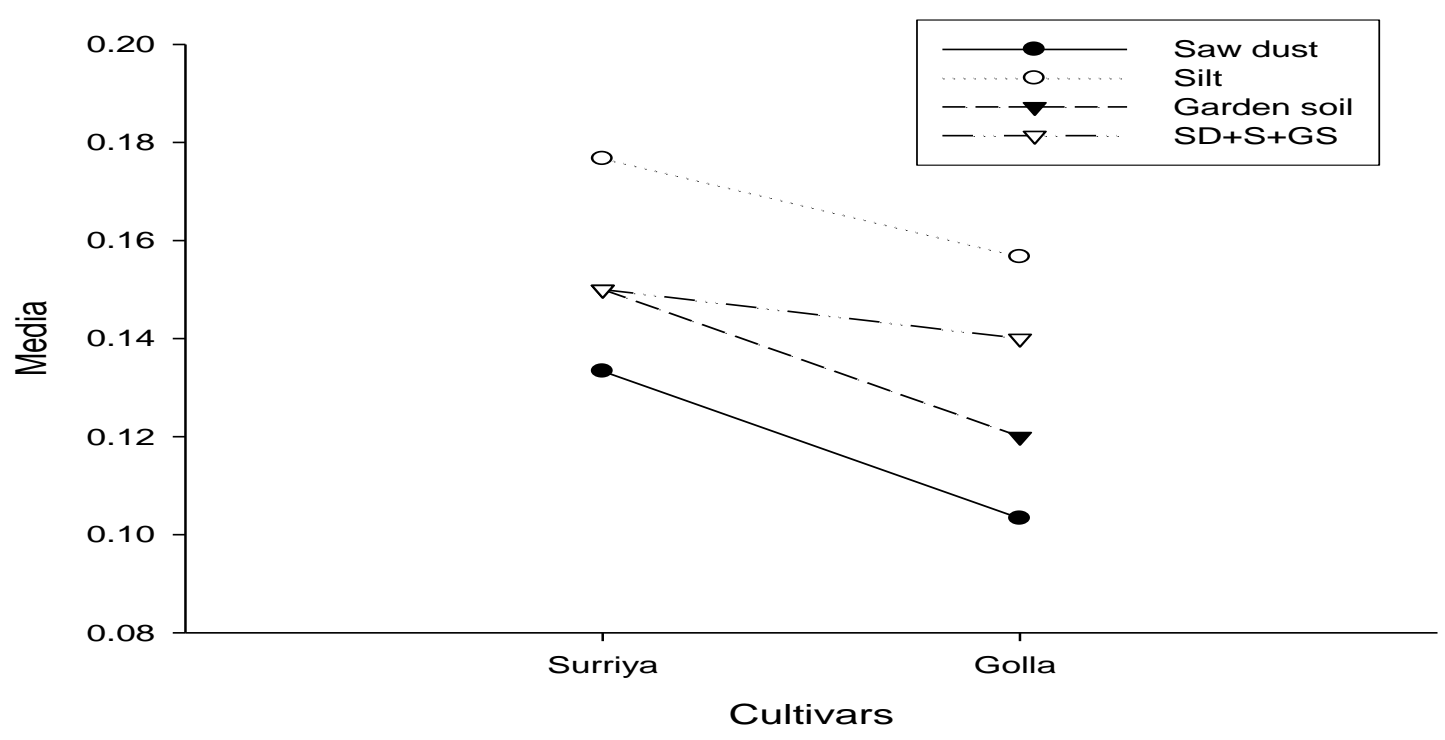

Figureure 2. Interactive effect of cultivars and growing media on root diameters Root length (cm)

Data regarding on root length $(\mathrm{cm})$ plant $^{-1}$ of Litchi cultivars were significantly affected by different growing media, interaction of cultivars and media were also found significant (Table-1). Maximum root length $(3.35 \mathrm{~cm})$ plant $^{-1}$ was obtained at Surriya cultivar while Golla cultivar resulting minimum root length $(2.91 \mathrm{~cm})$ plant $^{-1}$ of Litchi cultivar. Higher roots length (3.61 $\mathrm{cm})$ plant $^{-1}$ was found in media silt, least number of roots length $(2.45 \mathrm{~cm})$ plant $^{-1}$ was noted in Sawdust media. Interactive effect of Litchi cultivar Surriya and silt media performed better on the number of roots plant $^{-1}$ as compared to cultivar Golla and other media (Sawdust, Ground soil and $\mathrm{SD}+\mathrm{GS}+\mathrm{S}$ ) (Figure. 3). The silt does have more pore spaces as compared to the garden soil and hence, more nutrients were available. This was followed by the saw dust media that's why silt showed better results. 
Similar results have also been reported by [9]. In case of interactions for root length, maximum root length of was attained by cvSurriya having air layer combination of saw dust, silt and garden soil. Further addition to the stress was caused by the gradual increase in temperature from 22 to $42^{\circ} \mathrm{C}$ (with $20^{\circ} \mathrm{C}$ difference) and low humidity range (57 to $78 \%$ ) during the following months that caused delay in root development and reduced the success percentage in layered branches. On the other hand, gradual decrease in temperature from 38 to $25^{\circ} \mathrm{C}$ (with $13^{\circ} \mathrm{C}$ difference) and high humidity range (76 to $86 \%$ ) from August to December favored early root development and also increased success percentage in the branches when layering was practiced in August. However, the layered branches did not differ significantly for their survival after detachment.

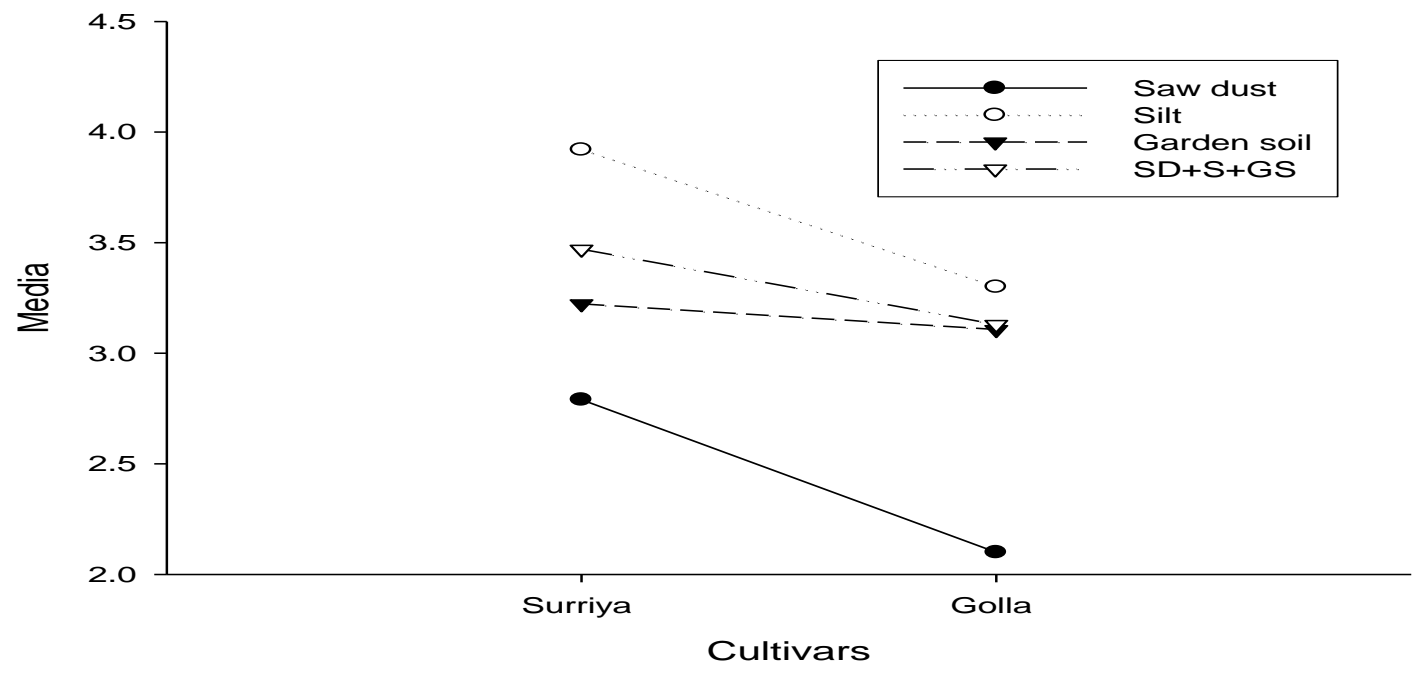

Figure 3.Interactive effect of cultivars and growing media on root length $(\mathrm{cm})$

Number of days to appearance

Number of days to appearance plant $^{-1}$ of Litchi cultivars was significantly affected by different growing media, interaction of cultivars and media were found nonsignificant (Table 1). Maximum number of days taken to appearance (26.58) plant $^{-1}$ was obtained at Golla cultivar while Surriya cultivar resulting minimum days to appearance (25) plant $^{-1}$ of Litchi cultivar. Higher number of days (29) to appearance plant $^{-1}$ was found in media Sawdust, least number of days (23) to appearance plant ${ }^{-1}$ was noted in Silt media. It seems that saw dust does not have more nutrients as compared to the silt, silt have more water holding capacity than that of garden soil, that's why silt media showed better results for rooting and our results are an agreements with the findings of [9]. Who noticed that the appearance was maximum in silt, while minimum in media saw dust.

\section{Survival percentage (\%)}

Data regarding survival \% of Litchi cultivars were significantly affected by different growing media, interaction of cultivars and media were found non-significant (Table-1). Maximum percentage of survival (79.17) plant $^{-1}$ was obtained at Surriya cultivar while Golla cultivar resulting minimum survival percentage (66.67) plant $^{-1}$ of Litchi cultivar. Higher survival $(83.33 \%)$ was found in media silt, least survival $(50 \%)$ plant $^{-1}$ was noted in Sawdust media. The poorest performance of rooted cuttings in saw dust soil might have been due to the nutritionally 
poor medium that resulted in the minimum values of all the parameters under study.

[13] Reported that, silt material improved soil fertility by increasing soil aeration, water holding capacity and water infiltration. The lesser growth in saw dust also might have been due to the minimum number of leaves and shoots that reduced the rate of photosynthesis, thereby reducing the plant growth and survival. High survival of rooted cuttings in these soil media reflected the fact that these combinations might have provided favorable physical conditions and sufficient nutrients to the cuttings needed for activating enzymatic and biochemical processes [12].

\section{Conclusion and Recommendation}

On the basis of above results cultivar Surriya and silt media significantly affected all the growth parameters such as Number of roots plant ${ }^{-1}$, root diameter, root length, days to appearance and survival percentage and also their interactive affect were found significantly. Litchi cultivar Surriya and silt media recommended for the agro-climatic condition of Malakand.

\section{Authors' contributions}

Conceived and designed the experiments: $\mathrm{H}$ Muhammad \& F Ghafoor, Performed the experiments: G Gul, S Faisal \& U Anwar, Analyzed the data: A Kamal, T Ahmad \& F Ullah, Contributed reagents/ materials/ analysis tools: A Shah, S Rawan \& S Rahman Wrote the paper: N Khan.

\section{References}

1.Menzel CM (1983). The control of floral initiation of lychee: A review. Sci Hort 21: 201-215

2.Lake B (1988). Lychees. Growth in Queensland Industry. Australian Hort 863: 80-81.

3.Anon (1991). Tissue culture of lychee (Litchi chinensis Sonn.). In: CSFRI Information Bulletin 229: 1-2.
4.Chapman KR (1984). Sapindaceae: Lychee. In: Page PE (Ed), Tropical tree fruits for Australia. Brisbane: Queensland Department of Primary Industries. Pp. 179-191.

5.Kantharanjah AS, McConchie CA \& Dodd WA (1992). In vitro embryo culture and induction of multiple shoots in lychee. Annals of Bot 70: 153-156

6.Durzan DJ (1984). Applications of plant tissue culture to Agriculture and Forestry. An overview. Symposium on Plant Cell and Tissue Culture. University of Tennessee, Knoxville, Sept 9-14, pp. 23-25.

7.Fu L \& Tang D (1983). Introduction pollen plants of Litchi tree (Litchi chinensisSonn.). ActaGeneticaSinica 10: 369-374.

8.Steel RGD, Torriea JH \& Dickey DA (1997). Principle and procedure of statistic. A biometrical approach, 3rd ED. MCGRAW Hill Book Co. Inc. New York. Pp.172-177.

9.Awan AA, Iqbal A, Rehman J \& Idris G (2002). Response of olive hard wood cutting to different growth media and basal injuries for propagation. Asian $J$ Plant Sci 2(12): 883-886.

10. Droll PW (2005). Orchid watering decisions. Orchids 74:770-775

11. Harbaugh BK, DeVoll DA \& Zalewski R (2000). Phosphorus fertilization for caladium tuber production on organic soil. Hort Tech 10(1): 169-171.

12. Wazir MG, Amin N, Khan I \& Khan MI (2004). Effects of different potting mixtures and nitrogen source on the performance of Brassica seedlings-II. Sarhad JAgric 20(1): 25-31.

13. Mathad MC \& Nalwadi UG (1989). Rooting ability of some important ornamental climbers. South Indian Hort 37(5): 307-308. 